\title{
CHANGES IN OXYGEN CONSUMPTION INDUCED BY FENTANYL AND THIOPENTONE DURING BALANCED ANAESTHESIA
}

\author{
DWayne R. Westenskow and William S. Jordan
}

KNOWLEDGE of whole body oxygen consumption $\left(\dot{\mathrm{V}}_{2}\right)$ is important in understanding tissue metabolism, tissue perfusion needs, ${ }^{1}$ and in determining the demand for oxygen transfer and transport placed upon the cardopulmonary system. Several studies suggest that with induction of general anaesthesia $\mathrm{VO}_{2}$ falls 15 to 20 per cent below basal levels. ${ }^{5}$ There seems to be no way of accurately predicting an individual patient's $\mathrm{V}_{2}$ during general anaesthesia and little is known regarding the magnitude of change which occurs during anaesthesia. ${ }^{6}$

This lack of information is probably due to the difficulty of measuring $\dot{\mathrm{V}}_{\mathrm{O}_{2}}$ during anaesthesia. The conventional closed circuit spirometer method for measuring $\dot{V}_{2}$ is not appropriate during anaesthesia because it cannot distinguish between the uptake of oxygen and the uptake of an anaesthetic gas. A second conventional method, often employing the mass spectrometer and a pneumotachograph, assumes that the number of molecules of nitrous oxide inhaled equals the number exhaled, which is frequently not the case even hours after anaesthetic induction with nitrous oxide. ${ }^{7}$ Correction for these problems has been applied by a number of investigators but their methods are not continuous and often require long time-intervals between serial determinations..$^{3.6 .7}$ Development of a system which can be easily applied to the anaesthesia setting has made continuous real-time data available for study of $\dot{\mathrm{V}}_{2}$ during nitrous oxide anaesthesia. ${ }^{8,9}$ The purpose of this study is to document transient changes in whole body $\dot{\mathrm{V}}_{2}$ following a bolus dose of thiopentone or fentanyl during nitrous oxide anaesthesia in man.

\section{MethoDs}

Seventeen unselected patients were studied

Dwayne R. Westenskow, Ph.D., Research Instructor of Anesthesiology and Surgery, and William S. Jordan, M.D., Associate Professor of Anesthesiology. Department of Anesthesiology, University of Utah College of Medicine, 50 North Medical Drive, Salt Lake City, Utah, 84132.

Canad. Anaesth. Soc. J., vol. 25, no. 1, January 1978 during elective operations under balanced anaesthesia (fentanyl, thiopentone, muscle relaxant and nitrous oxide). One hour after premedication (atropine, scopolimine, diazepam, and meperidine), anaesthesia was induced with fentanyl, thiopentone or diazepam, a muscle relaxant was given and the patient was intubated with a cuffed tracheal tube. Following intubation the lungs were ventilated using a semi-open circuit with fresh gas flows of $31 / \mathrm{min}$ oxygen and $31 / \mathrm{min}$ nitrous oxide. After 15 to 20 minutes the anaesthesia circuit was closed and oxygen and nitrous oxide were added through two parastolic roller pumps. The oxygen pump speed was controlled to maintain a constant inspired oxygen fraction (0.5) while the nitrous oxide pump was controlled to maintain constant circuit volume. The inflow of oxygen gave a continuous measure of the patient's whole body $\dot{\mathrm{V}}_{2}$ throughout the case. This measure of $\dot{\mathrm{V}}_{2}$ was found to correlate well ( $r=$ 0.94) with a standard $\dot{\mathrm{V}}_{2}$ measurement and to have an accuracy of \pm six per cent. ${ }^{9}$

After induction of anaesthesia the patient's blood pressure and heart rate were monitored every five minutes. Diastolic and systolic blood pressures were measured by ausculatation of Korotkoff sounds over the brachial artery. Heart rate was measured by a stethoscope placed over the suprasternal notch. Repeated doses of fentanyl or thiopentone were given whenever there was a ten per cent rise in blood pressure or heart rate. The dosage was selected to return heart rate and blood pressure to normal without causing cardiovascular depression. As each repeated dose of fentanyl or thiopentone was given $\dot{\mathrm{V}}_{2}$ was recorded immediately before and 5, 10 and 15 minutes after the infusion.

As a control, seven patients were given an intravenous bolus dose of fentanyl or thiopentone 10 to 15 minutes after the previous dose, when the blood pressure and heart rate were not elevated above normal. Again $\mathrm{Vo}_{2}$ was recorded before and 5,10 and 15 minutes after the infusion. Statistical significance of changes from control were determined using the Student's t-test for paired samples. 
$s d=9.5$
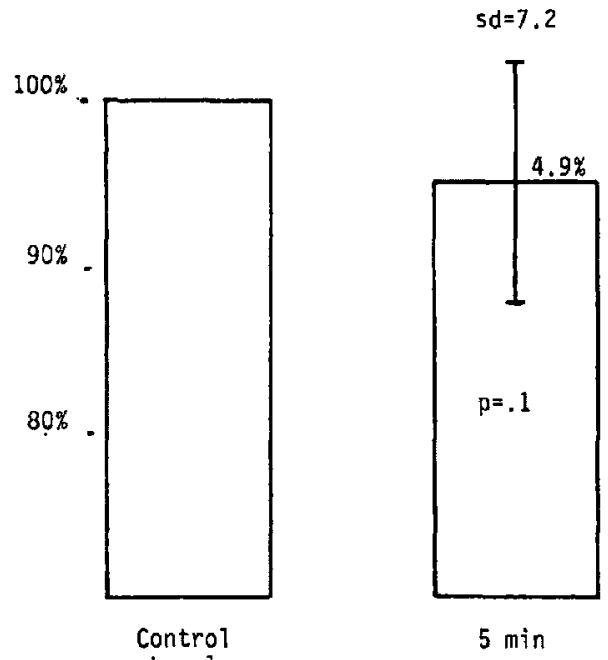

FIGURE 1. A verage percentage change in $\dot{\mathrm{V}}_{2}$ following a single bolus fentanyl infusion.
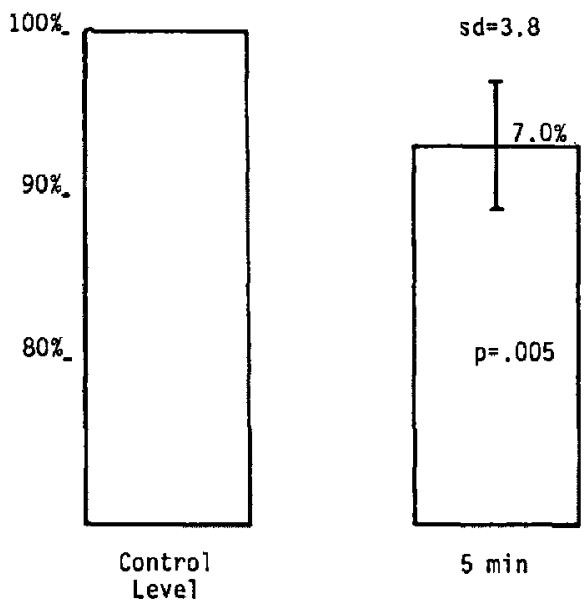

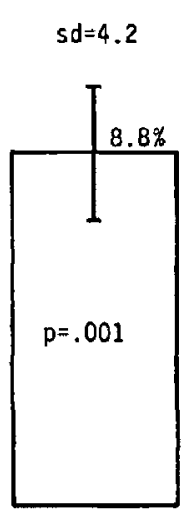

$10 \mathrm{~min}$

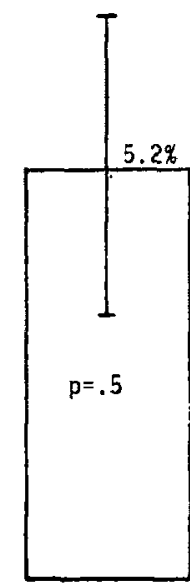

$15 \min$

Figure 2. Average percentage change in oxygen consumption following single bolus thiopentone infusion.

\section{Results}

Whole body $\dot{\mathrm{V}}_{2}$ decreased following repeated doses of fentanyl and thiopentone during balanced anaesthesia. In those patients receiving fentanyl, $\dot{V}_{2}$ decreased an average of $4.9,8.4$ and 5.2 per cent at 5,10 and 15 minutes after the infusion (Figure 1). After thiopentone $\mathrm{V}_{2}$ decreased an average of $7.0,8.8$ and 1.9 per cent at 5,10 and 15 minutes after the infusion (Figure 2). With both fentanyl and thiopentone the change in $\dot{\mathrm{V}}_{2}$ after 10 minutes was statistically significant 
from control $(P<0.005)$. The data are presented in tabular form in Table I and Table II.

In those patients showing no elevation of blood pressure or heart rate at the time of the infusion, there was no significant change in $\dot{\mathrm{V}}_{2}$ following the infusion of either fentanyl or thiopentone. These data are shown as the control group in Table I and Table II.

\section{Discussion}

The results of this study demonstrate that single intravenous doses of fentanyl ( 0.05 to 0.14 $\mathrm{mg}$ ) and thiopentone ( 30 to $225 \mathrm{mg}$ ) given during a "balanced anaesthesia" technique can cause significant decreases in whole body $\dot{\mathrm{V}}_{2}$. However, if the dose is given when the patient is showing no sign of decreasing depth of anaesthesia, $\dot{\mathrm{V}}_{2}$ does not change. It is believed that the effects of fentanyl and thiopentone on total $\dot{\mathrm{V}}_{2}$ are caused mainly by a decrease in cerebral oxygen consumption $\left(\mathrm{CMRO}_{2}\right)$ and in myocardial oxygen consumption ( $\mathrm{MVO}_{2}$ ).

A decrease in $\mathrm{CMRO}_{2}$ with thiopentone infusion in man has been reported by several investigators. ${ }^{10-12}$ In these studies the decrease following thiopentone varied from 30 to 55 per cent and was somewhat related to the total dose. As $\mathrm{CMRO}_{2}$ accounts for approximately 20 per cent of the total $\mathrm{VO}_{2}$ in man, ${ }^{13}$ a 40 per cent fall in $\mathrm{CMRO}_{2}$ would result in an eight per cent reduction in total $\dot{\mathrm{V}}_{2}$. In our study it is also very likely that $\mathrm{MVO}_{2}$ decreased following the thiopentone and fentanyl doses because heart rate and blood pressure, the principle determinants of myocardial work, decreased slightly. Though other organs could be and probably are involved in contributing to the overall decrease in $\mathrm{V}_{2}$, changes in cerebral and myocardial metabolic rate are the most obvious contributors and are likely the most important.

Many physiological parameters affect metabolic rate during general anaesthesia including body temperature, ${ }^{14}$ skeletal muscle activity ${ }^{15-16}$ and passive hyperventilation. ${ }^{17}$ None of these factors were considered as contributing variables in this study because each set of measurements was taken over a short 15 -minute period using every patient as his own control. During each 15-minute period temperature changes were insignificant, ventilation remained unchanged, and all patients were paralyzed to avoid skeletal muscle activity. The only disturbance to the preparation was the drug infusion itself.
TABLE I

Oxygen Consumption after INFUSion of Fentanyi,

\begin{tabular}{lcrrrr}
\hline \hline & & \multicolumn{3}{c}{$\begin{array}{c}\text { Oxygen consumption (ml/min } \\
\text { STPD) }\end{array}$} \\
\cline { 3 - 6 } & Dose (mg) & Control & 5 min & $10 \mathrm{~min}$ & $15 \mathrm{~min}$ \\
\hline LA & 10 & 259 & 248 & 240 & 232 \\
HA & .15 & 286 & 283 & 279 & 290 \\
NE & .05 & 182 & 194 & 174 & 174 \\
PA & .10 & 279 & 252 & 252 & 255 \\
FI & 10 & 224 & 224 & 194 & 224 \\
JO & .05 & 263 & 252 & 252 & 294 \\
FO & .05 & 341 & 286 & 283 & 283 \\
SA & .10 & 201 & 178 & 182 & 170 \\
\cline { 2 - 6 } Mean & & 254 & 240 & 232 & 240 \\
Standard deviation & 51 & 39 & 43 & 49 \\
Control group & & & & \\
EA & .05 & 143 & 147 & 151 & 151 \\
CR & .05 & 224 & 228 & 221 & 213 \\
PA & 10 & 259 & 263 & 263 & 259 \\
LU & .05 & 228 & 221 & 232 & 224 \\
\cline { 2 - 6 } Mean & & 214 & 215 & 217 & 212 \\
Standard deviation & 50 & 49 & 47 & 45 \\
\hline
\end{tabular}

TABLE II

OXYGEN CONSUMPTION AFTER INFUSION OF THIOPENTONE

\begin{tabular}{|c|c|c|c|c|c|}
\hline \multirow[b]{2}{*}{ LA } & Dose (mg) & Control & $5 \mathrm{~min}$ & $10 \mathrm{~min}$ & $15 \mathrm{~min}$ \\
\hline & 50 & 240 & 228 & 224 & 228 \\
\hline $\mathrm{HA}$ & 225 & 294 & 279 & 275 & 275 \\
\hline$A R$ & 75 & 209 & 182 & 194 & 205 \\
\hline $\mathrm{NE}$ & 30 & 209 & 201 & 182 & 224 \\
\hline$\overline{C R}$ & 50 & 232 & 217 & 213 & 240 \\
\hline $\mathrm{PA}$ & 100 & 290 & 252 & 240 & 259 \\
\hline$F I$ & 190 & 217 & 205 & 201 & 209 \\
\hline $\mathrm{DA}$ & 125 & 182 & 174 & 174 & 186 \\
\hline \multicolumn{2}{|c|}{ Mean } & 234 & 217 & 213 & 228 \\
\hline \multicolumn{2}{|c|}{ Standard deviation } & 40 & 35 & 33 & 29 \\
\hline \multicolumn{6}{|c|}{ Control group } \\
\hline AR & 125 & 186 & 190 & 194 & 197 \\
\hline FO & 50 & 252 & 271 & 259 & 259 \\
\hline MO & 50 & 325 & 333 & 329 & 325 \\
\hline $\mathrm{PA}$ & 100 & 228 & 240 & 252 & 240 \\
\hline \multirow{2}{*}{\multicolumn{2}{|c|}{$\begin{array}{l}\text { Mean } \\
\text { Standard deviation }\end{array}$}} & 248 & 259 & 259 & 255 \\
\hline & & 58 & 60 & 55 & 53 \\
\hline
\end{tabular}

It has been postulated that thiopentone would cause transient decreases in $\dot{\mathrm{V}}_{2}$ as repeated doses are given. ${ }^{10}$ The results of this study show that $\dot{\mathrm{V}}_{2}$ is indeed transiently reduced, not only with subsequent doses of thiopentone, but also with doses of fentanyl. 


\section{SUMMARY}

Changes in whole body oxygen consumption due to bolus infusions of fentanyl and thiopentone given during "balanced anaesthesia" have been examined in 17 patients. It has been shown that fentanyl causes an average decrease in oxygen consumption of $4.9,8.4$, and 5.2 per cent at 5 , 10 and 15 minutes after its infusion. Thiopentone causes an average decrease of $7.0,8.8$, and 1.9 percent at 5,10 and 15 minutes after infusion. It is believed that the effects of fentanyl and thiopentone on oxygen consumption are caused mainly by decreases in cerebral and myocardial oxygen consumption.

\section{RÉSUMÉ}

La consommation d'oxygène de 17 malades a été étudiée après des doses intraveineuses de thiopentone et de fentanyl administrées en bolus au cours d'anesthésies "balancées". Le fentanyl abaisse la consommation d'oxygène de $4.9,8.4$ et de 5.2 pour cent, 5,10 et 15 minutes après son administration. Celle-ci s'abaisse par ailleurs de $7,8.8$ et 1.9 pour cent aux mêmes intervalles, soit 5,10 et 15 minutes après administration de thiopental. Nous croyons que cette diminution est principalement attribuable à une consommation d'oxygène réduite au niveau du cerveau et du myocarde.

\section{ACKNOWLEDGEMENTS}

The authors wish to thank Drs. T. Stanley, N. Pace, and $W$. Martin for advice in preparing this manuscript.

\section{REFERENCES}

1. Gump, F.E. Oxygen consumption and caloric expenditure in surgical patients. Surg. Gynecol. Obstet. 137: 499 (1973).

2. Severinghaus, J.W. \& Cullen, S.C. Depression of myocardium and body oxygen consumption with fluothane. Anesthesiology 25: 627 (1964).
3. Shackman, R., Graber, G.l., \& Redwood, C. Oxygen consumption and anesthesia. Clin. Sci. 10: 219 (1951).

4. TheYe, R.A. \& Tuorr, G.F. Oxygen uptake during light halothane anesthesia in man. Anesthesiology 25: 627 (1964)

5. Nunn, J.F., Bergman, N.A., \& Coleman, A.J. Factors influencing the arterial oxygen tension during anesthesia with artificial ventilation. $\mathrm{Br} . \mathrm{J}$. Anesth. 37: 898 (1965).

6. Nisbet, H.I.A., Dibeinson, T.L.. Thomas, T.A. et al. Oxygen uptake in ventilated children during methoxylurane anesthesia. Can. Anesth. Soc. J. 20: 334 (1973).

7. Nunn, F.F. \& Poulior, J.C. The measurement of gaseous exchange during nitrous oxide anesthesia. Brit. J. Anesth. 34: 752 (1962).

8. WESTENSKOW, D.R., JOHNSON, C.C., \& JoRDAN, W.S. Instrumentation for continuous oxygen consumption during anesthesia. Proceedings of the 28th Annual Con, of Eng, in Med. and Biol. p. 476 (1975).

9. Westenskow, D.R., Johnson, C.C., Jordan, W.S. et al. Instrumentation for continuous oxygen consumption of critically ill and surgical patients. 1.E.E.E. Trans. Biomed. Eng. $24: 331-337$ (1977).

10. THEYE, R.A. Thiopental and oxygen consumption. Anesth. and Analg. 49: 69(1970).

11. Wechsler, R.L., Dripps, R.D. \& Kety, S.S Blood flow and oxygen consumption of the human brain during anesthesia produced by thiopental. Anesthesiology 12: 308 (1951).

12. Schieve, J.F. \& WILSON. W.P. The influence of age, anesthesia and cerebral arteriosclerosis on cerebral vascular activity to $\mathrm{CO}_{2}$. Amer. J. Med. 15: 171 (1953).

13. WADE, O.L. \& BISHOP, J.M. Cardiac output and regional blood flow. Oxford, Blackwell Scientific Publications, p. 268 (1962).

14. Spurr, G.B., Hutt, B.K., \& Horvath, S.M. Responses of dogs to hypothermia. Amer. J. Physiol. 179: 139 (1954)

15. Thung, N., Herzog, P., Christlieb II, et al. The cost of respiratory effort in post-operative cardiac patients. Circulation 28: 552 (1963).

16. WILSON, R.S., SUlLivan, S. F. MALM, J.R., et ai The oxygen cost of breathing following anesthesia and cardiac surgery. Anesthesiology 39: 387 (1973).

17. CAIN, S.M. Increased oxygen uptake with passive hyperventilation of dogs. J. of Appl. Phys. 28: 4 (1970). 